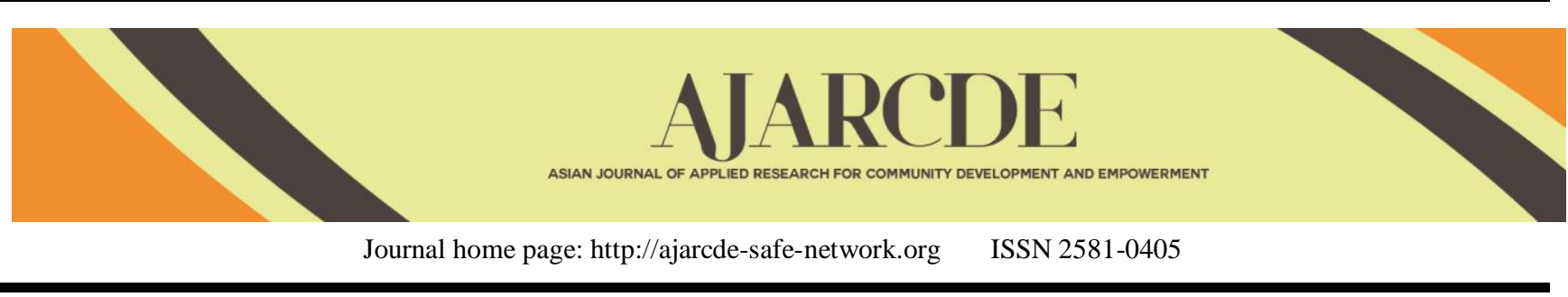

\title{
The Holistic Components of Cattle Production for Solving the Haze In Chiang Mai
}

\author{
Sermkiat Jomjunyong ${ }^{1}$ and Wallratat Intaruccomporn ${ }^{2}$ \\ ${ }^{1}$ Industrial Engineering Department, Faculty of Engineering, Chiang Mai University, Thailand 50200 \\ ${ }^{2}$ Department of Agricultural Economy and Development, Faculty of Agriculture, Chiang Mai University, Thailand 50200 \\ *Corresponding author: sermkiatj@gmail.com
}

\begin{tabular}{|c|c|}
\hline ARTICLE INFO & 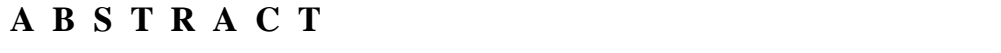 \\
\hline Article History: & \multirow{8}{*}{$\begin{array}{l}\text { Chiang Mai air pollution has persisted in crisis for more than a decade. This issue continues to } \\
\text { exist owing to the government has failed in addressing related policies and/or explicit solutions } \\
\text { to cope with adopting carrier of farmers. This research found that farmers are familiar with } \\
\text { cattle raising because this has been an important part of the country since ancient times. } \\
\text { Therefore, cattle production is not only safe economically but also sound indigenously and } \\
\text { ecologically. This research was conducted in Mae Chaem District's Ban Thab Sub-districts of } \\
\text { Chiang Mai, where slash and burn corn has been dominant for maize plantation. Participatory } \\
\text { Action Research (PAR) was implemented throughout interviewing and observing to collect data } \\
\text { from } 14 \text { farmers in the selected area. Then the data was analyzed by the inductive approach and } \\
\text { descriptive statistics to identify essential components for the sustainability of cattle production. } \\
\text { Results yield by the participants indicate that cattle production is the potential to replace slash } \\
\text { and burn for monoculture due to its advantages. }\end{array}$} \\
\hline Received: July 3, 2019 & \\
\hline Final Revision: November 14, 2019 & \\
\hline Available Online: December 13, 2019 & \\
\hline KEYWORDS & \\
\hline Haze Pollution, Cattle, Chiang Mai Pollution & \\
\hline CORRESPONDING AUTHOR & \\
\hline *E-mail: sermkiatj@gmail.cc & \\
\hline
\end{tabular}

\section{INTRODUCTION}

Chiang Mai is one of the most important economic provinces of Thailand owing to the specific topography that has drawn both domestic and international tourists around 7.4 million to visit annually [1]. However, the socio-economic structure that changes dynamically has not only affected the way of life but also the environmental quality caused principally by slash-and-burn culture for the plantation of cash crops and monoculture of maize [2].

In a similar way of Thai regions and other counties in Southeast Asia, slash-and-burn has been a popular practice in Chiang Mai since the 1960s. This method describes how to prepare fields for the new agricultural season by cutting and burning farmlands or natural forests [3]. In general, slash-andburn within the province occurs yearly during February to April, and most of it is intentionally done as it can offer farmers, especially who are marginal in time, finance and labor, to accomplish an agricultural system of rotation and intercropping [4]. To promote the yield of expensive puffball mushrooms (Astraeus odaratus) called "het tawp" is another reason [5]. Consequently, these man-made forest fires not only lead to soil erosion and biodiversity loss but also fatal haze, especially PM2.5 dust particles, that have been suffering Chiang Mai population's health [6].

Empirically the Chiang Mai air pollution has persisted in crisis for more than a decade. There are pieces of evidence indicate that the quantity of haze and the incident of wildfire are associated, of which amongst 8 northern provinces of Thailand
Chiang Mai is the most affected area in terms of frequency and size (Figure 1-2).

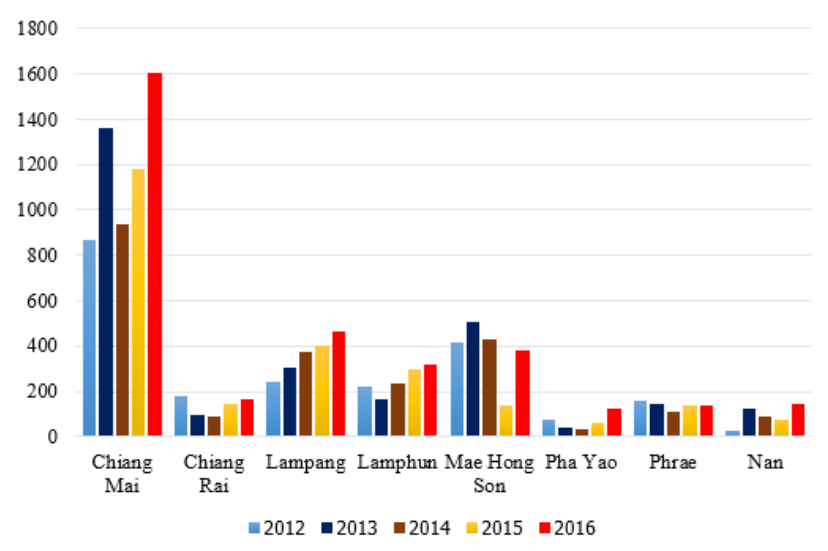

Figure 1 The annual comparison of the frequency of fire incidents during $2012-16$ in 8 provinces in northern Thailand [7].

However, this issue continues to exist owing to the government has failed in addressing related policies and/or explicit solutions to cope with adoping carrier of farmers [8]. The situation is likely to be worsened drastically, and cannot be solved by the law enforcement likewise other problems. Penalties for public burning are already existed, but mild and inefficiently enforced [9]. In addition, the topography of Chiang Mai itself has been unfavorable to tackle the haze. Surrounded by the mountain valleys contributes haze arduous to slip pass, therefore high concentrations of harmful substances are easy reached. More 
unfortunately, this was more terrible in a few years ago because El Nino that had caused the average rainfall absence [10].

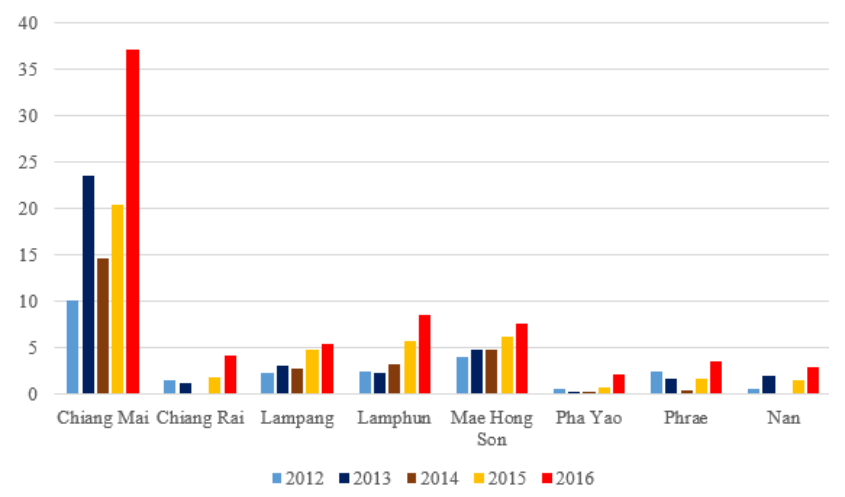

Figure 2 The annual comparison of the impact areas $(\mathrm{km} 2)$ during $2012-16$ in 8 provinces in northern Thailand [7].

The Chiang Mai air pollution has raised an alarm again at both the national and global scales in 2019 when the amount of haze on several days reached the no.1 spot of the world's worst airpolluted cities. The level of PM2.5 particles in days was measured at over 500 microns, 10 times the safety level [11]. This is an urgent issue owing to the polluted air contributes one-third of deaths from stroke, lung cancer, and heart disease are due to its consequences. A high level of PM2.5 particles also boosts autism and Alzheimer cases amongst children and adults, respectively. Besides, the toxic level of pollution approximately reduced tourism earnings by 10,000 million baht [12].

To avoid those undesirable situations, there were short-term and long-term solutions established by related stakeholders, for examples, promoting health awareness through the rally called "Bye Bye Smog." Fertilizing fixed plots and cultivation leguminous crops and/or fruit trees rather than slashing and burning for monoculture plantations were also recommended. However, the tide is still beyond from a sea of change owing to an income and the physical methods are not attractive as the traditional slash and burn.

Both theoretically and practically, one of the solutions considered as an alternative against the haze is cattle production, reasoning farmers can convert green waste such as corn stalks and rice straws, which have been annually expected for being burned before land preparation, into their animal food and nutrient cycling [13]. Besides, most farmers are familiar with cattle raising because this has been an important part of the country since ancient times. Therefore, cattle production is not only safe economically but also sound indigenously and ecologically [14].

\section{METHODOLOGY}

The study was carried out from February to September 2018 by interdisciplinary researchers from Chiang Mai University and Department of Livestock Development and Sub-district Administration Organization. This study was conducted in Mae Chaem District's Ban Thab Sub-districts of Chiang Mai, where slash and burn corn has been dominant for maize plantation. Participatory Action Research (PAR) was implemented throughout interviewing and observing to collect data from 14 farmers in the selected area. Then the data was analyzed by the inductive approach and descriptive statistics to identify essential components for the sustainability of cattle production. Related studies were also reviewed to propose those components valid in theory.

\section{RESULTS}

Results yield by the participation indicate that cattle production is potential to replace slash and burn for monoculture due to its advantages, for example, green waste can be fermented as a nutrient instead of useless burning. However, there are components at various levels needed to operate to make the cattle production holistic in terms of alternative farming against the haze.

At the individual and household level, Thai native breeds are more appropriate than imported generic types. Although Thai native breeds have been often criticized about their slow growth rate, small size, and low carcass yields. However, they are robust naturally to local outbreaks and heat of Thailand. Also, Thai native breeds are marketable and well-adapted to low quality feeds, and in particular have high fertility and good mothering ability that suit to smallholders who are limited in assets.

At the local level, a set of required knowledge, skills, and inputs to farmers, who are looking to abandon slash and burn for monoculture, have to be transferred by the local governmental authorities. For instance, teaching farmers how to ferment animal food. Only the consequences of this knowledge, green waste will be reused from February to April to reduce significantly the opportunity of burning. The other is cattle will be healthier to meet consumers' demands owing to fermented food consists of probiotic and protein higher than raw food in the surrounding environment [15]. Facilitating and encouraging farmers to delivery and exchange knowledge to other farmers should be another inevitable role of those authorities.

In this level, the Sufficient Economy Philosophy's second stage focused on group cooperation can be utilized to design the marketing plan. After cattle are fed to be fattening, for example, selling cows and buffalos to nearby Muslims and tribal people respectively during their ritual ceremonies are recommended. This business will not only benefit sellers higher regarding the demand and supply model of microeconomics but also empower their autonomy from economic pressures from the outside. Besides, because cattle are expensive assets, therefore trading activities should be supervised by co-operative groups rather than individuals. Importantly, farmers have to sell cattle in terms of weight to enhance their bargain power over middlemen.

At the national level, there are practical policies in supporting cattle production. The possibilities include: empowering farmers to access to services such as infrastructures. This is key to enable farmers, especially smallholders in rural areas of Chiang Mai, can overcome the imbalance power caused by their educational level and limited assets; supporting farmers to mitigate risks such as natural disasters and price variations to ensure that cattle keepers can produce a large enough marketable surplus to conquer poverty; creating policies aimed at enhancing cattle productivity comprise of essential actions intended to manage farmers' access to animal health services and credit. 
Table 1 A policy framework for the sustainability of cattle production against slash and burn

\begin{tabular}{|c|c|c|c|}
\hline ঐ্ٍ & Policy goal & Example of policy & Key actor \\
\hline 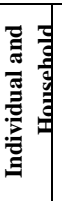 & $\begin{array}{l}\text { Enhancing the } \\
\text { capacity of self- } \\
\text { dependence and } \\
\text { competitiveness }\end{array}$ & $\begin{array}{l}\text { Teaching how to practically } \\
\text { integrate the Sufficient Economy } \\
\text { Philosophy in cattle production } \\
\text { Informing advantages of raising } \\
\text { Thai native breeds } \\
\text { Advertising to self-reliant }\end{array}$ & $\begin{array}{l}\text { Farmers and } \\
\text { their family } \\
\text { members }\end{array}$ \\
\hline త్ర & $\begin{array}{l}\text { Increasing the } \\
\text { ability to absorb } \\
\text { disturbances } \\
\text { while } \\
\text { remaining } \\
\text { productive and } \\
\text { profitable }\end{array}$ & $\begin{array}{l}\text { Educating farmers short-term and } \\
\text { long-term benefits of cattle } \\
\text { production for abandoning slash } \\
\text { and burn for monoculture } \\
\text { Transferring required knowledge } \\
\text { and inputs, for example, how to } \\
\text { ferment food from green waste and } \\
\text { selling cattle in terms of weight } \\
\text { instead of number } \\
\text { Setting educational platforms for } \\
\text { exchanging knowledge between } \\
\text { and/or amongst farmers within a } \\
\text { community } \\
\text { Building up cooperative for } \\
\text { increasing bargain power } \\
\text { Supporting access to provincial } \\
\text { agribusiness partnerships } \\
\text { Providing real-time data of air } \\
\text { conditions during the smoky } \\
\text { season and guiding how to mitigate } \\
\text { its effects }\end{array}$ & $\begin{array}{l}\text { Collective } \\
\text { action } \\
\text { amongst } \\
\text { farmers, local } \\
\text { governmental } \\
\text { authorities, } \\
\text { and } \\
\text { provincial } \\
\text { population }\end{array}$ \\
\hline है & $\begin{array}{l}\text { Convincing } \\
\text { farmers to } \\
\text { abandon slash } \\
\text { and burn for } \\
\text { securing haze } \\
\text { free Chiang Mai }\end{array}$ & $\begin{array}{l}\text { Establishing cattle insurance and } \\
\text { cattle health services } \\
\text { Supporting access to national or } \\
\text { international agribusiness } \\
\text { partnerships } \\
\text { Limiting imported cattle from } \\
\text { abroad } \\
\text { Providing "soft loaning" to } \\
\text { potential farmers for further } \\
\text { investments } \\
\text { Constructing infrastructures } \\
\text { Enforcing the existed laws and } \\
\text { regulations related to man-made } \\
\text { forest fires } \\
\text { Collecting data to develop and } \\
\text { monitor policies for coping with } \\
\text { haze } \\
\text { Creating and enforcing payments } \\
\text { for environmental services }\end{array}$ & $\begin{array}{l}\text { The central } \\
\text { government }\end{array}$ \\
\hline
\end{tabular}

In addition, cattle production has never been sustainable if the government does not lead farmers to the outside world at crossscale linkages. The government should facilitate farmers to expand their production with other sectors (private, public, and non-governmental organizations) in fund-raising, marketing, and technological management. If farmers reach successfully this point, slash and burn for monoculture will be decreased gradually owing to they are secured economically, socially, and environmentally by cattle production.

\section{CONCLUSION}

Cattle production has the enormous potential to substitute slash and burn due to its direct and indirect benefits. It offers farmers a sustainable farming occupation. The demand for cattle, especially high-quality beef with high marbling sold at the modern-trade market, has been increasing every year while the capacity of the domestic production is still insufficient [16]. If cattle production is adopted widely, abundant green waste from post-harvesting will be looked like a valuable capital and disposed of in a positive way. Many scientific studies have confirmed one mature cow alone will averagely consume $10.8 \mathrm{~kg}$ dry matter on a daily basis [17]. The related study also states the burning of green waste such as leaves and grass only $10.8 \mathrm{~kg}$ can release about $0.57 \mathrm{~kg}$ of carbon monoxide $(\mathrm{CO})$ and $0.20 \mathrm{~kg}$ of hazard particulates [18]. This refers during 61 days of March and April, of which is the time period of man-made forest fires that have been commonest in Chiang Mai, in each year not only 334 $\mathrm{kg}$ dry matter is invisible but also $34.77 \mathrm{~kg}$ of CO and $12.2 \mathrm{~kg}$ of poisonous particulates are absent by a cow's intakes. Nevertheless, the number of cattle raised must be accordant to the ability to ferment food of the availability of household labors. Self-reliant based on the Sufficient Economy Philosophy is an excellent action to avoid the opening of new agricultural lands for the sake of grazing. Besides, the dependence on household labors is against negative outcomes of the labor shortage in needed times.

However, external interventions supported by stakeholders and the government are still required in aspects at variously operational levels. For examples, at the local level, agricultural extension officers have to distribute knowledge in an active manner. Delivering know how of breeding, nutrition and healthcare will be the principal targets owing to cattle production is on a relatively high degree of risks such as animal diseases. This is compounded by cattle production requires a long time of feeding to earn an input. To solve this, a soft loaning and subsidies that acknowledge farmers' unique ways of managing financial assets, committing to forward sales and revenue is the solution to persuade farmers abandoning monoculture permanently. More importantly, if farmers are recognized in the performance of livestock management, helping them to expand the business by constructing local slaughterhouses should be optional. This is the win-win situation for both farmers and consumers in Thailand.

The government must limit the import of cattle from abroad and considers the import as a short-term strategy against cattle scares. This imported limitation should be done at the same time with establishing institutional mechanisms that link farmers more directly to consumers or at least to retail vendors. These are the holistic components to increase farmers' opportunities in the business competition [16].

There are a few components outside the farm gate needed the government to pay attention to cope with the haze of Chiang Mai. Introducing campaigns for raising public awareness is one of the priorities. Accurate and timely information about provincial air situations and how to mitigate it can be a powerful tool to cope with the effects of polluted air. For examples, the Ministry of Public Health made a statement of outdoor activities and strenuous physical sports are rather unhealthy to engage in during the smoky season. Chiang Mai University and other educational institutions had temporarily suspended their classes for the sake of students when the province entered the global list of worst air pollution. During that time civil and governmental organizations also implemented a tangible short-term solution with handing out people free N95 masks.

Most importantly, the existed legal mechanisms must be updated and fairly enforced by the government authorities particularly at the local level. Payments for environmental services in a similar way of developed countries is also. This scheme has been considered as an effective instrument to make 
farmers, land owners or mega-firms, who are a part of slash and burn, aware of the conservation of natural resources. These suggestions must be implemented immediately to change the profit equation for the stakeholders in a way that the costs of damaging behavior win over individual interest. Because, simply, the opportunity in breathing clean air is the basic rights to life, health, and wellbeing of all Chiang Mai population

\section{ACKNOWLEDGMENT}

This study was funded by National Research Council of Thailand under the Haze Free Thailand Project

\section{REFERENCE}

[1]. National Statistical Office. 2015. Thailand, Situation to Domestic Traveler, Chiang Mai Province: 2009-2015. [Online] Available: http://stat.dopa.go.th/Stat/Statnew/upstat_age_disp.php [15 May 2019].

[2]. Liwa Pardthaisonga, Phaothai Sin-ampola, Chanida Suwanprasita, Arisara Charoenpanyaneta. 2018. Haze Pollution in Chiang Mai, Thailand: A Road to Resilience. Paper prepared for presentation at the 7th International Conference on Building Resilience "Using Scientific Knowledge to Inform Policy and Practice in Disaster Risk Reduction.” 27 - 29 November 2017. Bangkok, Thailand.

[3]. Schmidt-Vogt, Dietrich. 1998. "Defining Degradation: The Impacts of Swidden on Forests in Northern Thailand." Mountain Research and Development.18: 135-149.

[4]. Downey, S. S. 2010. "Can Properties of Labor-Exchange Networks Explain the Resilience of Swidden Agriculture?" Ecology and Society. 15(4): 15.

[5]. Keegan H. Kennedy, James F. Maxwell and Saisamorn Lumyong, 2012. "Fire and the Production of Astraeus odoratus (Basidiomycetes) sporocarps in Deciduous dipterocarp-oak forests of Northern Thailand." Maejo International Journal of Science and Technology. 6(3): 483-504.

[6]. The Nation. 2019. Chiang Mai Haze Shortening People's Lives, Warns Doctor. [Online]. Available: https://www.nationmultimedia.com/detail/national/3036 5841 [2 June 2019].

[7]. Forest Fire Control Division National Park. 2017. Forest Fire Description [Online] Available: http://www.dnp.go.th/forestfire/Eng/description.htm [2 June 2019]

[8]. The Nation. 2019. Chiang Mai Could Open Haze Refugee Centre. [Online]. Available: https://www.nationmultimedia.com/detail/national/3036 6502 [29 May 2019].

[9]. Atchara Rakyutidharm. 2001. The Experience of Forest Fire Management by Local Communities. Northern Watershed Development by Community Organization Project. Chiang Mai: Northern Development Foundation.

[10].Nion Sirimongkonlertkul1, Preecha Upayokhin, and Vivarad Phonekeo. 2013. "Multi-Temporal Analysis of Haze Problem in Northern Thailand: A Case Study in
Chiang Rai Province." Kasetsart Journal of Natural Science. 47: 768-780.

[11].WHO. 2000. Guidelines for Air Quality. Geneva: World Health Organization.

[12].WHO. 2016. Ambient Air Pollution: A Global Assessment of Exposure and Burden of Disease. Geneva: World Health Organization

[13].Steinfeld, H. 1998. "Livestock and their Interaction with the Environment: An Overview." BSAP Occasional Publication. 21: 67-76.

[14]. Georges Félix. 2015. From Slash and Burn to 'Slash and Mulch.' [Online]. Available: https://www.ileia.org/2015/03/22/slash-burn-slashmulch/ [2 June 2019].

[15].FAO. 2016. Probiotics in Animal Nutrition: Production, Impact, and Regulation. Rome: FAO.

[16].Matana Osothongs, Jirayut Khemsawat, Mattaneeya Sarakul, Danai Jattawa, Thanathip Suwanasopee, and Skorn Koonawootrittriron. 2016. Current Situation of Beef Industry in Thailand. Paper prepared for presentation at the Proceeding of International Symposium "Dairy Cattle Beef Up Beef Industry in Asia: Improving Productivity and Environmental Sustainability" 19 August 2016. Bangkok, Thailand.

[17].Rasby, Rick. 2013. Determining How Much Forage a Beef Cow Consumes Each day. [Online]. Available: https://beef.unl.edu/cattleproduction/forageconsumedday?fbclid=IwAR3HJ6GibuzY2qD-F6R1wP4xclY8RTydVCkdmoMyLA5LF-nZJNEKukaUwk [10 June 2019].

[18].Curtis, Luke. 2002. "Biomass burning: Wood, Leaves, Grass, Forests, Crops and Trash." Burning Issues. (Nov11.). 